DOI: https://doi.org/10.31933/jimt.v2i6 Received: 14 Juni 2021, Revised: 25 Juni 2021, Publish: 15 Agustus 2021

JIMT
DINASTI
JUENAL ILMU MANAJEMEN
TERAPAN

\title{
PENGARUH PROMOSI PENJUALAN TERHADAP KEPUTUSAN IMPULSE BUYING PADA TRONA SUPERMARKET JAMBI TOWNSQUARE (STUDI KASUS PADA MAHASISWA FAKULTAS EKONOMI UNIVERSITAS BATANGHARI)
}

\author{
Pupu Sopini $^{1}$, Akhmad Irwansyah Siregar ${ }^{2}$, Sadarman Zebua ${ }^{3}$ \\ 1) Fakultas Ekonomi Universitas Batanghari, Jambi, Indonesia, email: \\ pupusopini08@gmail.com \\ 2) Fakultas Ekonomi Universitas Batanghari, Jambi, Indonesia, email: \\ akhmad.irwansyah.siregar@unbari.ac.id \\ 3) Fakultas Ekonomi Universitas Batanghari, Jambi, Indonesia, email: \\ sadarmanzebua2@gmail.com
}

\begin{abstract}
Abstrak: Promosi penjualan adalah bentuk persuasi langsung melalui penggunaan berbagai insentif yang dapat diatur untuk merangsang pembelian produk secara langsung dan/atau meningkatkan jumlah barang yang dibeli oleh pelanggan. Pembelian impulsif dapat diartikan sebagai bagian dari suatu kondisi yang disebut "pembelian yang tidak direncanakan". Tujuan dari penelitian ini adalah untuk mengetahui bagaimana pengaruh promosi penjualan terhadap Impulse Buying mahasiswa Fakultas Ekonomi Universitas Batanghari pelanggan Trona Supermarket Jambi Town Square Penelitian ini merupakan penelitian lapangan (Field Research) dengan menggunakan metode analisis kualitatif dan Analisis kuantitatif. Teknik pengumpulan data dalam penelitian ini menggunakan angket dan dokumentasi. Sampel penelitian adalah 113 mahasiswa Fakultas Ekonomi Universitas Batanghari Jambi secara purposive sampling. Metode analisis data dengan metode Analisis Regresi Sederhana, Koefisien Determinasi $\left(\mathrm{R}^{2}\right)$, dan uji-t. Hasil penelitian menunjukkan bahwa: terdapat pengaruh yang signifikan antara variabel kualitas produk $(\mathrm{X})$ terhadap keputusan pembelian impulsif (Y) Supermarket Trona Jambi Town Square pada mahasiswa Fakultas Ekonomi Universitas Batanghari Jambi yang dibuktikan dengan nilai thitung sebesar 8,982, nilai thitung ini akan dibandingkan dengan nilai ttabel. $(8,982>1,981)$ dan nilai R Square adalah 0,421 .
\end{abstract}

Kata Kunci: Promosi Penjualan dan Keputusan Impulse Buying.

\section{PENDAHULUAN}

Pada era perdagangan bebas yang serba modern seperti saat ini, tingkat persaingan bisnis yang tinggi membuat perusahaan berlomba-lomba untuk mempertahankan dan memenangkan persaingan pasar serta memperluas eksistensinya. Industri sejenis akan selalu 
berusaha memperebutkan pasar yang sama. Salah satu industri yang sangat berkembang saat ini yaitu industri ritel, yang semakin hari persaingannya semakin kompetitif.

Imbas dari persaingan itu tentunya sangat jelas dimana konsumen kemudian menjadi semakin kritis memilih yang terbaik dan paling menguntungkan.Banyaknya industri ritel saat ini menyebabkanT masyarakat memiliki lebih banyak alternatif untuk memenuhi kebutuhan mereka.

Beberapa contoh perusahaan retail adalah minimarket, supermarket, shopping center, mall dan department store. Seperti yang diungkapkan Kotler dan Amstrong (2003) Usaha eceran (Retail) adalah suatuusaha yang kegiatannya menyangkut penjualan barang atau jasa secara langsungkepada konsumen untuk penggunaan pribadi dan non-bisnis.

Berbagai kebutuhan pribadi dan rumah tangga tersedia di berbagai toko ritel, terutama di Kota Jambi mulai dari makanan, minuman, pakaian, perlengkapan rumah tangga, accesesoris, dan lain-lain. Hal ini dilakukan untuk memenuhi permintaan dan kebutuhan konsumen agar mampu bersaing dengan toko ritel lainnya.

Fisher dalam Negara dan Dharmmesta (2003) mendefinisikan impulse buying sebagai kecenderungan konsumen untuk membeli secara sepontan, reflek, tiba-tiba, dan otomatis. Dari definisi tersebut terlihat bahwa impulse buying merupakan sesuatu yang alamiah dan merupakan reaksi yang cepat. Impulse buying bisa terjadi dimana saja dan kapan saja. Termasuk pada saat seorang penjual menawarkan suatu produk kepada calon konsumen. Dimana sebenarnya produk tersebut terkadang tidak terpikirkan dalam benak konsumen sebelumnya.

Menurut Rook dan Fisher, perilaku pembelian impulsif di dorong oleh stimulus yaitu alat komunikasi penjualan dan kegiatan promosi yang berfungsi sebagai rangsangan pemasaran (Duarte, raposo \& Ferazz, 2013). Salah satu strategi stimulus yang membentuk pembelian seketika adalah Sales Promotion. Bentuk sales promotion yang dilakukan untuk meningkatkan penjualan diantaranya adalah diskon harga, hadiah gratis, dan banded atau penjualan bersama-sama (bundling) dan lainnya.

Berdasarkan penjelasan diatas maka peneliti tertarik untuk melakukan penelitian dengan judul, "Pengaruh Promosi Penjualan Terhadap Keputusanimpulse Buying pada Trona Supermarket Jambi Town Square (Study Kasus Pada Mahasiswa Fakultas Ekonomi Universitas Batanghari)".

Berdasarkan penjabaran latara belakang di atas, maka tujuan penelitian ini sebagai berikut:

1. Untuk mengetahui bagaimana Promosi Penjualan pada Trona Supermarket Jambi Town Square.

2. Untuk mengetahui bagaimanaImpulse Buying pada Mahasiswa Fakultas Ekonomi Universitas Batanghari.

3. Untuk mengetahui bagaimana Pengaruh Promosi Penjualan terhadap Impulse BuyingMahasiswa Fakultas Ekonomi Universitas Batanghari pelangganTrona Supermarket Jambi Town Square.

\section{KAJIAN PUSTAKA Manajemen}


Menurut Hasibuan (2012) manajemen adalah ilmu dan seni mengatur proses pemanfaatan sumber daya manusia dan sumber-sumber lainya secara efektif dan efisien untuk mencapai suatu tujuan tertentu. Menurut Terry dalam Badrudin (2017) mendefinisikan manajemen sebagai suatu proses khas yang terdiri atas tindakan-tindakan perencanaan, pengorganisasian, penggerakan dan pengendalian yang dilakukan untuk menentukan serta mencapai sasaran yang telah ditentukan melalui pemanfaatan sumber daya manusia dan sumber daya lainnya. Jadi dapat disimpulkan bahwa manajemen adalah ilmu atau seni yang mengatur proses pemanfaatan sumber daya manusia.

\section{Manajemen Pemasaran}

Menurut Mursid (2003) manajemen pemasaran merupakan konsep ilmu dalam strategi bisnis yang bertujuan untuk mencapai kepuasan berkelanjutan bagi skateholder (pelanggan, karyawan, dan pemegang saham).Dari pengertian diatas dapat disimpulkan bahwa manajemen pemasaran adalah suatu upaya untuk mengelola dan mempertahankan hubungan baik dengan konsumen agar saling menguntungkan antara individu atau kelompok dalam melakukan kegiatan usahanya.

\section{Promosi Penjualan}

Menurut Kotler dan Keller (2012) promosi penjualan (salespromotion) merupakan bahan inti dalam kampanye pemasaran, terdiri dari koleksi alat insentif, sebagian besar jangka pendek, yang dirancang untuk menstimulasikan pembelian yang lebih cepat atau lebih besar atas produk atau jasa tertentu oleh konsumen atau perdagangan.Cummins \& Mullin (2004) promosi penjualan adalah upaya yang dilakukan pemasaran untuk mendorong calon pembeli agar membeli lebih banyak dan lebih sering.

Menurut Tjiptono (2008) promosi penjualan adalah bentuk persuasi langsung melalui pengguanaan alat-alat insentif yang beragam untuk mendorong pembelian suatu produk atau jasa tertentu secara cepat dan meningkatkan jumlah barang yang di beli konsumen.

Sedangkan, Menurut Hermawan (2012) promosi penjualan merupakan aktivitas pemasaran yang mengusulkan nilai tambah dari suatu produk(untuk mendapatkan lebih dari sekedar yang ada dari nilai produk) dalam jangka waktu tertentu dalam rangka mendorong pembelian konsumen.

\section{Keputusan Impulse Buying}

Menurut pendapat Rook dan Fisher dalam G.Muruganantham \& Bhakat (2013), mengatakan bahwa pembelian impulsif diartikan sebagai kecenderungan konsumen membeli secara spontan, reflek, tiba-tiba, dan otomatis.Dapat dikatakan bahwa pembelian impulsif adalah sesuatu reaksi pembelian yang alamiah dan terjadi secara cepat.

Menurut Mowen dan Minor (2001), definisi pembelian impulsif (adalah tindakan membeli yang dilakukan tanpa memiliki masalah sebelumnya atau maksud/niat membeli yang terbentuk sebelum memasuki toko.Intinya pembelian impulsif dapat dijelaskan sebagai pilihan yang dibuat pada saat itu juga karena perasaan positif yang kuat mengenai suatu benda. Dengan kata lain faktor emosi merupakan "tanda masuk" ke dalam lingkungan dari orang-orang yang memiliki gairah yang sama atas segala sesuatu barang.

Sedangkan menurut Schiffman dan Kanuk (2007) pembelian impulsif merupakan keputusan yang emosional atau menurut desakan hati.Emosi dapat menjadi sangat kuat dan kadangkala berlaku sebagai dasar dari motif pembelian yang dominan.

Kotler dan Keller (2012) menjelaskan bahwa proses pengambilan keputusan adalah proses psikologis dasar yang memainkan peranan penting dalam memahami bagaimana konsumen secara aktual mengambil keputusan pembelian. Saatkonsumen membeli sebuah 
produk, pada umumnya konsumen mengikuti suatu proses atau tahapan dalam pengambilan keputusan.

\section{Hubungan Antar Variabel}

Menurut Duarte, et, al (2013) pembelian secara impulsive buying sering dipicu dan didorong oleh faktor-faktor yang lain dalam lingkungan belanja,seperti promosi penjualan rangsangan dalam strategi pemasaran ini dapat didorong dari produk itu sendiri, harga, atau posisi produk tersebut. Sedangkan menurut Kurniawan dan Kunto faktor-faktor yang mempengaruhi impulse buying adalah promosi, store atmoshpere, shopping emotion. Menurut Saladin dan Oesman (2002) Promosi berkaitan dengan komunikasi informasi penjual dan pembeli yang bertujuan untuk merubah sikap dan tingkah laku pembeli, yang sebelumnya tidak mengenal menjadi mengenal sehingga menjadi pembeli dan mengingat produk tersebut.

\section{Kerangka Pemikiran}

Dari kajian teori dan hubungan antar variable penelitian dan berdasarkan tujuan riset maka kerangka riset ini adalah seperti di bawah ini.

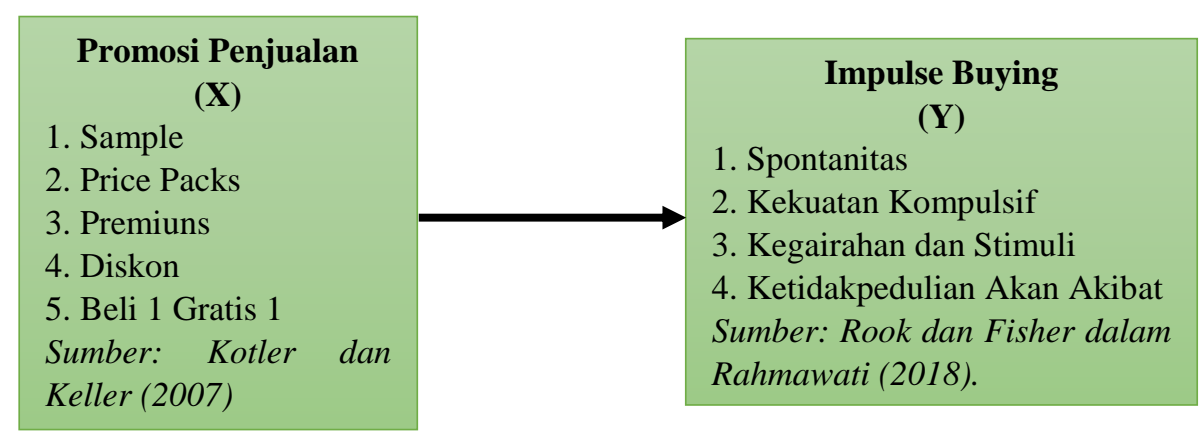

\section{Gambar 1}

Bagan Kerangka Pemikiran

\section{Hipotesis Penelitian}

Hipotesis adalah suatu perumusan terhadap rumusan masalah yang diajukan oleh peneliti, dijabarkan dari landasan teori dan masih harus diuji kebenaranya. Karena bersifat sementara, maka dibuktikan kebenarannya melalui data yang terkumpul atau penelitian ilmiah. Hipotesis dinyatakan ditolak atau diterima. Dari uraian sebelumnya maka penulis membuat hipotesis sebagai berikut:

$\mathrm{H}_{\mathrm{o}}$ : Promosi Penjualantidak berpengaruh terhadap keputusan impulse buying pada Mahasiswa Fakultas Ekonomi Universitas Batanghari pelanggan Trona Supermarket Jamtos.

$\mathrm{H}_{\mathrm{a}}$ : Promosi Penjualan berpengaruh terhadap keputusan impulse buying pada Mahasiswa Fakultas Ekonomi Universitas Batanghari pelanggan Trona Supermarket Jamtos. 


\section{METODE PENELITIAN}

Metode penelitian yang digunakan pada penelitian ini yaitu metode deskriptif kuantitatif. Dimana metode kuantitatif menurut Sugiyono (2017) merupakan metode penelitian yang berlandaskan pada filsafat positivisme, digunakan untuk meneliti pada populasi atau sampel tertentu, pengumpulan data menggunakan instrumen penelitian, analisis data bersifat kuantitatif/statistik, dengan tujuan untuk mengaju hipotensis yang telah ditetapkan.

\section{Jenis dan Sumber Data}

\section{Jenis Data}

Adapun data yang digunakan dalam penelitian ini adalah:

a. Data Primer. Data primer menurut Sugiyono (2015) adalah sumber data yang langsung memberikan data kepada pengumpul data.Data primer diperoleh dari menyebar kuesioner kepada Mahasiswa Fakultas Ekonomi Universitas Batanghari yang bersedia menjadiresponden dan mengisi kuesioner.

b. Data Sekunder. Data sekunder menurut Sugiyono (2015) adalah sumber data yang tidak langsung memberikan data kepada pengumpul data, misalnya lewat orang lain atau lewat dokumen. Data sekunder penelitian ini adalah diperoleh dari media cetak, media elektronik, maupun jurnal penelitian sebelumnya yang relevan dengan kegiatan penelitian ini.Sumber Data

2. Sumber Data

Adapun sumber data dalam penelitian ini berasal dari:

a. Fakultas Ekonomi UNBARI.

b. Kuesioner

\section{Metode Pengumpulan Data}

Untuk Data yang diperoleh dalam penelitian ini dilakukan dengan cara :

1. Penelitian Lapangan (Field Reseach).

Yaitu penelitian yang dilakukan langsung ke objek penelitian guna memperoleh datadata primer dan informasi secara terperinci dengan menggunakan teknik-teknik sebagai berikut :

a. Wawancara, yaitu pengumpulan data dengan tanya jawab langsung dengan pihakpihak yang berkepentingan dalam memberikan keterangan dan data-data yang dibutuhkan dalam penelitian.

b. Kuesioner, yaitu dengan mengajukan sejumlah pertanyaan tertulis terhadap para konsumen.

c. Observasi, yaitu dengan pengamatan langsung di fakultas ekonomi Universitas Batanghari Jambi.

\section{Penelitian Kepustakaan (Library Research)}

Yaitu suatu metode pengumpulan data yang dilakukan dengan mempelajari literatureliteratur, buku-buku yang sesuai dengan bidang yang diteliti guna mendapatkan data berupa teori-teori yang relevan dengan permasalahan yang diteliti. 


\section{Populasi dan Sampel}

1. Populasi

Populasi adalah keseluruhan subjek penelitian (Arikunto,2013:173). Yang menjadi populasi dalam penelitian ini adalah mahasiswa fakultas ekonomi UNBARI.

\section{Sampel}

Sampel adalah sebgaian atau wakil populasi yang diteliti (Arikunto,2013:174). Metode yang digunakan dalam penarikan sampel yaitu Convinience Sampling, yaitu proses pemilihan sampling berdasarkan ketersediaan eemen dan kemudahan untuk mendapatkan dengan kata lain sampel diambil atau dipilih karena sampe tersebut ada pada tempat dan waktu yang tepat. Maka dalam penelitian ini, peneliti mengambil sampel dari populasi konsumen yang mengacu pada pendapat slovin dengan margin error 5\%, sehingga di peroleh sampel 100 responden.

\section{Metode Analisis Data}

Dalam penelitian ini, metode yang digunakan adalah analisis deskriptif dan analisis regresi linear sederhana.Analisis data dalam penelitian ini dibantu dengan software SPSS.

\section{Analisis Deskriptif}

Analisis deskriptif adalah metode analisis dengan pendekatan kuantitatif yang bertujuan menggambarkan secara sistematis menggunakan skala likert. Skala Likert, yaitu dengan memberikan nilai dari setiap pertanyaan yang diberikan dalam daftar pertanyaan. Nilai skor setiap variable ditentukan pada rentang skala (Umar, 2005). Dengan rentang skala dapat diketahui skala penilaian setiap kriteria atau variable, yaitu sangat tidak baik, tidak baik, cukup baik, baik dan sangat baik. Adapun langkah-langkah perhitungan sebagai berikut:

a. Jawaban dari kuesioner terdiri atas 5 (lima) pilihan, sebagai berikut:

- Bobot $1=$ Sangat Tidak Puas

- Bobot $2=$ Tidak Puas

- Bobot $3=$ Cukup Puas

- Bobot $4=$ Puas

- Bobot $5=$ Sangat Puas

b. Menghitung skor tiap komponen dengan cara mengalikan seluruh frekuensi data dengan nilai bobotnya.

c. Menentukan rentang skala dengan menggunakan rumus (Umar, 2005).

Dimana :

$$
R s=\frac{n(m-1)}{m}
$$

Rs $=$ rentang skala

$\mathrm{n}=$ jumlah sampel

$\mathrm{m}=$ jumlah alternative jawaban tiap item

d. Menentukan rentang skor terendah dan tertinggi dengan cara mengalikan jumlah sampel random dengan bobot paling rendah dan paling tinggi,yaitu:

- Rentang skor terendah $=\mathrm{n} \times$ skor terendah atau $\mathrm{n} \times 1$

- Rentang skor tertinggi $=\mathrm{n} \times$ skor tertinggi ayau $\mathrm{n} \times 5$

- Membuat skala-skala penilaia tiap kriteria 
e. Membuat kesimpulan/keputusan

Kemudian diadakan perhitungan rentang skala

\section{Analisis Verifikatif}

Menurut Soeratno dan Rasyad (2008).Verifikasi merupakan hasil yang telah diperoleh dari suatu survey.Dalam analisis verifikasi menggunakan alat analisis regresi linear sederhana yang mendesrkripsikan teknik analisis dalam pengujian.

\section{a. Analisis regresi linear sederhana}

Analisis regresi adalah analisis yang meilupi metode-metode yang digunakan untuk memprediksi nilai-nilai dari satu atau lebih variable tergantug yang dihasilkan adanya pengaruh satu atau lebih variable bebas.Dalam penelitian ini digunakan regresi linear sederhana karena data-data yang ada didalam penelitian ini bersifat sederhana yaitu hanya ada satu variable dependen dan satu variable independen.

Regresi linear sederhana mengestimasi besarnya koefisien-koefisien yang dihasilkan dari persamaan linear yang melibatkan satu variable bebas untuk digunakan sebagai alat prediksi besarnya nilai variable tergantung. Penulis juga akan melakukan uju statistic analisis regresi untuk mengetahui ada atau tidaknya peran antara variable $X$ dan Y dengan menggunakan rumus sebagai berikut: $\mathbf{Y}=\mathbf{a}+\mathbf{b} \cdot \mathbf{X}+\mathbf{e}$

$$
\begin{aligned}
& \text { Keterangan: } \\
& \mathrm{Y}=\text { Promosi Penjualan } \\
& \mathrm{a}=\text { Konstanta } \\
& \mathrm{b}=\text { Koefisien regresi } \\
& \mathrm{X}=\text { Keputusan Impulse Buying } \\
& \mathrm{e}=\text { error }
\end{aligned}
$$

\section{b. Koefesien determinasi (R2)}

Menurut Hasan (2016) Koefisien determinasi adalah bagian dari keragaman tital variable terikat $(\mathrm{Y})$ yang dapat diterangkan atau diperhitungkan oleh keragaman variable bebas $(\mathrm{X})$.

\section{c. Pengujian hipotesis}

Uji parsial digunakan untuk menguji apakah variable bebas Promosi Penjualan (X) berpengaruh terhadap variable terikat Keputusan Impulse Buying (Y), Priyanto (2013: 37), signifikan pengaruh tersebut dapat didestiasi dengan membandingkan antara nilai $t$ hitung dengan nilai $\mathrm{t}$ tabel.Apabila nilai $\mathrm{t}$ hitung $>\mathrm{t}$ tabel maka variable independen secara individual mempengaruhi variable dependen, sebaliknya jika $t$ hitung $<\mathrm{t}$ tabel maka variable independen secara individual tidak mempengaruhi variable dependen.

1) Rumus hipotesis

$>\mathrm{H}_{0}: \mathrm{b}=0$, Artinya variable independen $(\mathrm{X})$ tidak berpengaruh terhadap variable dependen (Y)

$\mathrm{H}_{1}: \mathrm{b} \neq 0$, Artinya variable independen $(\mathrm{X})$ berpengaruh terhadap variable dependen $(\mathrm{Y})$

2) Tingkat signifikan $5 \%(\alpha=0,05)$

3) Kriteria keputusan:

$t_{\text {hitung }}>t_{\text {tabel }}$ bearti Ho ditolak dan H1 diterima

$t_{\text {hitung }}>t_{\text {tabel }}$ bearti Ho diterima dan H1 ditolak

Selain melalui Uji t, uji secara parsial juga bisa dilihat pada tingkat signifikan:

Jika tingkat signifikan $<0,05$ maka ho ditolak dan $\mathrm{H} 1$ diterima 
Jika tingkat signifikan > 0,05 maka ho diterima dan $\mathrm{H} 1$ ditolak

\section{HASIL DAN PEMBAHASAN}

Regresi Linear Sederhana

Dari nilai-nilai koefisien yang terdapat pada tabel persamaan regresi yang disusun untuk penelitian ini berdasarkan SPSS 22 sebagai berikut :

Tabel 1

Uji Regresi Linear Sederhana

\begin{tabular}{|c|c|c|c|c|c|}
\hline \multirow[b]{2}{*}{ Model } & \multicolumn{2}{|c|}{$\begin{array}{l}\text { Unstandardized } \\
\text { Coefficients }\end{array}$} & \multicolumn{3}{|l|}{$\begin{array}{l}\text { Standardized } \\
\text { Coefficients }\end{array}$} \\
\hline & B & Std. Error & Beta & $\mathrm{t}$ & Sig. \\
\hline 1 (Constant) & ,703 & ,323 & & 2,180 & 031 \\
\hline $\begin{array}{l}\text { Promosi } \\
\text { penjualan }\end{array}$ & ,839 & ,093 & ,649 & 8,982 & 000 \\
\hline
\end{tabular}

a. Dependent Variable: impulse buying berikut :

Berdasarkan tabel di atas dapat dibentuk persamaan regresi linear sederhana sebagai

$$
\begin{gathered}
Y=\mathbf{a}+\mathbf{b} . \mathrm{X}+\mathrm{e} \\
\mathrm{Y}=\mathbf{0 , 7 0 3}+\mathbf{0 , 8 3 9} . \mathrm{X}+\mathrm{e}
\end{gathered}
$$

Berdasarkan persamaan regresi linear sederhana diatas diketahui bahwa koefisien regresi kualitas produk bernilai positif. Dengan kata lain variabel kualitas produk dapat dijadikan alat untuk memprediksi keputusan impulse buying pada Mahasiswa Fakultas Ekonomi Universitas Batanghari Jambi. Diketahui nilai constant sebesar 0,703 artinya apabila variabelpromosi penjualan dianggap constant(bernilai 0), maka variabel keputusan impulse buying Mahasiswa Fakultas Ekonomi Universitas Batanghari Jambi akan bernilai 0,703 .

Koefisien variabelpromosi penjualan 0.839 artinya setiap terjadi kenaikan promosi penjualan sebesar $1 \%$ maka mengakibatkan keputusan impulse buyingpada Mahasiswa Fakultas Ekonomi Batanghari Jambi akan mengalami peningkatan sebesar 0,839.

\section{Koefisien Determinasi $\left(\mathbf{R}^{2}\right)$}

Koefisien determinasi dilambangkan dengan R2. Nilai ini menyatakan proporsi variasi keseluruhan dalam nilai dependen yang dapat diterangkan atau diakibatkan oleh hubungan linier dengan variable independen, selain itu (sisanya) diterangkan oleh variable lain. Hasil perhitungan SPSS untuk melihat koefisien determinasi dapat dilihat pada model summary berikut ini :

Tabel 2

Koefisien Determinasi

\begin{tabular}{|c|c|c|c|c|c|}
\hline Model & $\mathrm{R}$ & R Square & $\begin{array}{l}\text { Adjusted R } \\
\text { Square }\end{array}$ & $\begin{array}{l}\text { Std. Error of the } \\
\text { Estimate }\end{array}$ & $\begin{array}{l}\text { Durbin- } \\
\text { Watson }\end{array}$ \\
\hline 1 &, $649^{\mathrm{a}}$ & ,421 & ,416 & ,58422 & 1,942 \\
\hline
\end{tabular}

Model Summary ${ }^{b}$ 
a. Predictors: (Constant), Promosi penjualan

b. Dependent Variable: impulse buying

Koefisien korelasi dalam penelitian ini adalah 0,649 atau 6494\% artinya terdapat hubungan yang baik antara variabelpromosi penjualan $(\mathrm{X})$ terhadap keputusan impulse buying (Y) pada Mahasiwa Fakultas Ekonomi Univeristas Batanghari Jambi.

Berdasarkan hasil pengujian koefisien determinasi pada tabel diatas, menunjukkan bahwa nilai $\mathrm{R}$ Square sebesar 0.421 yang artinya bahwa besarnya kontribusi variabel independen promosi penjualan mempengaruhivariabel(Y)Impulse Buying sebesar $(0,421 \mathrm{x}$ $100=42,1 \%)$, sedangkan sisanya $(100 \%-42,1 \%=57.9 \%)$ dipengaruhi oleh variabelvariabel lain di luar penelitian ini.

\section{Pengujian Hipotesis}

Pengujian hipotesis pada penelitian ini dilakukan melalui uji t, dengan tujuan untuk mengetahui apakah secara individu (parsial) variable independen mempengaruhi variable dependen secara signifikan atau tidak. Hasil olahan SPSS 22.0 dapat dilihat:

Tabel 3

\begin{tabular}{llrr}
\multicolumn{4}{c}{ Uji Parsial (Uji t) } \\
\hline Model & $\mathrm{t}$ & \multicolumn{1}{c}{ Sig } \\
1 & (Constant) & 2,180 &, 031 \\
& Promosi penjualan & 8,982 &, 000 \\
\hline
\end{tabular}

a. Dependent Variable: impulse buying

Sumber: Data diolah SPSS 22.0

Dari tabel diatas maka di dapat nilai thitung sebesar 8,982, nilai thitung ini akan dibandingkan dengan nilai tabel $(8,982>1,981)$, maka keputusannya adalah Ho ditolak dan $\mathrm{H}_{\mathrm{a}}$ diterima. Dengan demikian ada pengaruh signifikan antara variabel kualitas produk $(\mathrm{X})$ terhadap keputusan impulse buying (Y) Trona Supermarket Jambi Town Square pada Mahasiswa Fakultas Ekonomi Universitas Batanghari Jambi.

\section{Pembahasan}

Berdasarkan persamaan regresi linear sederhana diketahui bahwa koefisien regresi kualitas produk bernilai positif. Dengan kata lain variabel kualitas produk dapat dijadikan alat untuk memprediksi keputusan impulse buying pada Mahasiswa Fakultas Ekonomi Universitas Batanghari Jambi. Diketahui nilai constant sebesar 0,703 artinya apabila variabelpromosi penjualan dianggap constant(bernilai 0), maka variabel keputusan impulse buying Mahasiswa Fakultas Ekonomi Universitas Batanghari Jambi akan bernilai 0,703.

Koefisien variabelpromosi penjualan 0.839 artinya setiap terjadi kenaikan promosi penjualan sebesar $1 \%$ maka mengakibatkan keputusan impulse buying pada Mahasiswa Fakultas Ekonomi Batanghari Jambi akan mengalami peningkatan sebesar 0,839.

Hal tersebut sejalan dengan yang dikemukakan oleh Cummins \& Mullin (2004) promosi penjualan adalah upaya yang dilakukan pemasaran untuk mendorong calon pembeli agar membeli lebih banyak dan lebih sering. Didukung dengan penelitian yang dilakukan oleh Ria Afriani (2011) dimana promosi penjualan berpengaruh positif terhadap impulse buying. Hal ini berarti jika promosi penjualan dilakukan sering atau dilaksanakan dengan baik maka akan meningkat daya beli dalam hal ini adalah impulse buying.

Berdasarkan hasil pengujian koefisien determinasi, menunjukkan bahwa nilai R Square sebesar 0.421 yang artinya bahwa besarnya kontribusi variabel independen promosi 
penjualan mempengaruhivariabel (Y) Impulse Buyingsebesar $(0,421 \times 100 \%=42,1 \%)$, sedangkan sisanya $(100 \%-42,1 \%=57.9 \%)$ dipengaruhi oleh variabel-variabel lain di luar penelitian ini.

Nilai $t_{\text {hitung }}$ sebesar 8,982 , nilai thitung ini akan dibandingkan dengan nilai tabel $(8,982>$ 1,981), maka keputusannya adalah Ho ditolak dan $\mathrm{H}_{\mathrm{a}}$ diterima. Dengan demikian ada pengaruh signifikan antara variabel kualitas produk (X) terhadap keputusan impulse buying (Y) Trona Supermarket Jambi Town Square pada Mahasiswa Fakultas Ekonomi Universitas Batanghari Jambi.

Hasil penelitian ini sejalan dengan peneltian terdahulu yang dilakukan oleh Ria Afriani (2011), Prcylia Wauran, Jane Grace Poluan (2016), dan Gilang Raafi Indarswari, S. Martono (2016) yang menyatakan bahwa promosi penjualan berpengaruh positif dan signifikan terhadap impulse buying.

Seperti yang dikemukakan oleh Kurniawan dan Kunto (2013) impulse buying sering dipicu dan di dorong oleh faktor-faktor lain dalam belanja, seperti store atmosphere, dan shopping emotion.

Berdasarkan hasil regresi linier sederhana, maka diperoleh kesimpulan bahwa promosi penjualan berpengaruh positif dan signifikan terhadapimpulse buying Trona Supermarket Jambi Town Square pada Mahasiswa Fakultas Ekonomi Universitas Batanghari.

\section{KESIMPULAN DAN SARAN}

\section{Kesimpulan}

Berdasarkan dari hasil penelitian dan pembahasan dari bab sebelumnya maka dapat diambil kesimpulan sebagai berikut :

1. Berdasarkan rekapitulasi jawaban responden maka dapat disimpulkan bahwa promosi penjualan pada Trona Supermarket Jambi Town Square tinggi. Responden menetapkan dimensi beli satu gratis satu tertinggi dengan skor 417,5, sedangkan jawaban terendah adalah muatan extra dengan skor 385, dan dimensi potongan harga 404.

2. Berdasarkan hasil rekapitulasi jawaban responden keputusan impulse buying pada mahasiswa Fakultas Ekonomi Universitas Batanghari Jambi tinggi. Dimana responden mendapatkan dimensi spontanitas tertinggi dengan skor 453, sedangkan jawaban responden terendah adalah ketidakpedulian akan akibat dengan skor 408, kekuatan kompulsif mendapat skor 437, dan dimensi kedaerahan dan stimulti mendapat skor sebesar 440 .

3. Berdasarkan hasil regresi linier sederhana, maka diperoleh kesimpulan bahwa promosi penjualan berpengaruh positif dan signifikan terhadapimpulse buying Trona Supermarket Jambi Town Square pada Mahasiswa Fakultas Ekonomi Universitas Batanghari.

\section{Saran}

Berdasarkan hasil penelitian dan pembahasan serta kesimpulan yang dijabarkan sebelumnya, penulis memberikan saran kepada PT. Samsung Elektronik sebagai berikut :

1. Untuk meningkatkan frekuensi dan memperluas wilayah promosi penjualan untuk lebih menarik minat beli dan ketertarikan konsumen utnuk melakukan impulse buying.

2. Untuk penelitian berikutnya agar menambahkan variabel-variabel lainnya seperti store atmosfer, gaya hidup, brand imageagar dapat mengeksplorasi kemungkinan variabel lain yang berpengaruh terhadap Impulse Buying. Serta melakukan penelitian ini dengan objek penelitian yang berbeda seperti modern market store yang lain. 


\section{DAFTAR RUJUKAN}

Assauri, Sofjan. 2010. Manajemen Pemasaran: Dasar, Konsep \& Strategi. Jakarta: Raja Grafindo Persada.

Boyd, W. L. 2000. Manajemen Pemasaran. Jilid 1. Edisi Kedua. Jakarta: Erlangga.

Djaslim, Saladin. 2010. Manajemen Pemasaran. Edisi Pertama. Bandung: Linda Karya.

Ferdinand, Agusty. 2006. Metode Penelitian Manajemen. Semarang: Badan penerbit Universitas Diponegoro.

Freddy, Rangkuti. 1997. Riset Pemasaran. Jakarta: PT. Gramedia.

Griffin, Jill. 2010. Customer Loyalty: Menumbuhkan dan Mempertahankan Kesetiaan Pelanggan. Alih Bahasa Dwi Kartini Yahya. Jakarta: Erlangga.

Komarrudin. 1991. Analisis Manejemen Produksi. Jakarta: Bumi Aksara.

Kotler, P . 1997. Prinsip-Prinsip Pemasaran, Cetakan Pertama, Jakarta: Erlangga.

Kotler, P. 2009. Manajemen Pemasaran 1, Edisi 13, Jakarta: Erlangga.

Kotler, P dan Armstrong, G. 2012. Prinsip-Prinsip Pemasaran, Edisi 13, Jilid 1, Jakarta: Erlangga.

Kotler, P dan Keller, K.L. 2009. Manejemen Pemasaran, Jilid 1, Alih Bahasa oleh Bob Sabran, Edisi 13. Jakarta: Erlangga.

Kotler, P dan Keller, K.L. 2012. Manajemen Pemasaran. Edisi 12. Jakarta: Erlangga.

Mursid, M. 2003. Manajemen Pemasaran. Jakarta: Bumi Aksara.

Nuraini, I. 2006. Pengantar Ekonomi Makro. Malang: UMM PRESS.

Orville, Larreche, dan Boyd. 2005. Manajemen Pemasaran. Jakarta: Erlangga.

Poli. 2002. Pengantar Ilmu Ekonomi. Jakarta: Prenhalido.

Riduwan. 2004. Metode dan Teknik Menyusun Tesis, Cetakan Pertama, Bandung: Alfabeta.

Santoso, Singgih. 2001. Metode Penelitian. Jakarta : Ghalia Indonesia.

Santoso, Singgih dan Tjiptono, T. 2004. Riset Pemasaran Konsep dan Aplikasi dengan SPSS. Jakarta: PT. Elex Media Komputindo

Siswanto, H. B. 2013. Pengantar Manajemen. Jakarta: Bumi Aksara.

Stanton, William J. 2005. Prinsip Pemasaran, Cetakan Ketujuh, Jakarta: Erlangga.

Sugiyono. 2011. Metode Penelitian Kuantitatif, Kualitatif, dan R\&D. Bandung: Alfabeta

Swastha, Basu. 2007. Manajemen Pemasaran Modern. Yogyakarta: Liberty Offset.

Terry, George R. 2001. Manajemen Dasar, Pengertian dan Masalah, Edisi Revisi, Cetakan 1. Jakarta: Penerbit Bumi Aksara.

Terry, George R. Dan Leslie W. Rue. 2010. Dasar-Dasar Manajemen, Cetakan Kesebelas, Jakarta: Bumi Aksara.

Tjiptono, Fandy . 2007. Strategi Pemasaran, Edisi 3, Yogyakarta: AndiOffset 